\title{
WOODS LABOUR TRAINING
}

\author{
BY E. R. GOULET ${ }^{1}$
}

At least two Canadian Pulp and Paper Association panels have discussed woods labour training recently: a panel of the Industrial Relations Section in the fall of 1961 and one of the Woodlands Section last March.

These discussions indicate that management at the upper echelons believes mechanization calls for more labour training and that Industrial Relations people in general share this idea, although the front line men in this latter group are not as enthused about it as in the horse and bucksaw days.

Three members of the Woodlands Section panel-E. E. Grainger, F. A. Harrison, and F. A. Roberts(1)-stressed that full mechanization will result in and require better trained labour. According to Grainger: "The problem is not so much finding financial support for this program as in determining the type of training required. Most companies in our industry have an on-the-job training plan, which I am sure is very effective in most cases. It is doubtful, however, if such plans will be adequate for the major training program which will be necessary with the advent of total mechanization."

Obviously some uncertainty exists about the type of training required and one wonders if some of us fully irealize just how work knowledge is passed from one blue-collar worker to another, how hardly practical it is to implement effective organized training programs in some spheres of woods work.

Is the cost of organized woods labour training justified when one considers that overall labour output has just doubled during the past decade and the forecast is that it will leap another 100 per cent during the coming decade? What other industry can boast similar progress?

In a typical woodlands division producing some 300,000 cunits, ten years ago camps opened at the end of August or early September, and a peak of 3000 men was needed. Today, camps are open from May until mid-March; cutting is usually completed by the end of December; and a peak of 1000 men is sufficient. With fully mechanized year-round operations, 400 to 500 men should suffice for this production.

All this has been accomplished with little or no organized labour training, except perhaps for safety, commissary, and forest fire control.

Let us now look at the present day Quebec worker. The woods labour pool in Quebec may be somewhat depleted, but it is still ample to meet the demand. In any case, it is a far cry from the immediate post war years, when scores of taxis toured the countryside in search of woodsworkers.

Does the present day woodcutter differ from his predecessor?

Let us see! $\mathrm{He}$ is 32 years of age-somewhat older; he has fifth grade schooling; he draws Unemployment Insurance Commission benefits for nine weeks in the year. Forest work is the main occupation of three out of four and two out of three intend to carry on as forest workers.

${ }^{\text {I }}$ Personnel Supervisor (Woods), Canadian International Paper Co., Montreal, P.Q. 
His brother, who works on a heavy machine and in the base shops, is five years older; he usually went to school a year longer. Thirty percent received some training from machine distributors or manufacturers; $25 \%$ claim having attended trades school, but very few completed the course. Almost all, except the older ones and those with hardly any schooling, are eager or at least say they are eager to receive more practical training. It is also of interest that $90 \%$ of this group are married compared with $50 \%$ of the woodcutters who do not enjoy the same security of employment.

Following a study of woods labour sponsored by Quebec Forest Industries Incorporated and conducted by the Faculty of Social Sciences of Laval University in 1956, Professors Fortin and Cosselin concluded in part (2):

(1)"Farming as a source of revenue is losing ground in areas where bucherons originate;

(2) The great majority of woodsworkers draw their income almost exclusively from the forest; and

(3) The marginal farmer who has become a professional woodsworker has the same attitudes as the industrial worker; he seeks short and long term security-year-round employment. If he does not find it in the forest, he will look for it somewhere else."

In the same issue, Tremblay (3) wrote:

"Forest work is becoming a specialized activity, but it may yet take a long time before this evolution has reached a point where individuals working in this industry are enjoying stability, can be proud of their trade and look at it as a desirable vocation for their children."

In a nutshell, here are the views of three field personnel men on the present day worker and the worker of tomorrow:

"Labour turnover is still high; it is a clear indication that the present level of mechanization has not changed either the labour force itself or the working context at large. Living and social conditions of the woodsworkers will continue to evolve or else we will have to be satisfied with the present day worker."

One added: "With regard to the training of woodcutters, it is thought that they do less than they know ... " Another reports that their training system calls for machine operators to work with the mechanics when their machines have to undergo major repairs; that logging instructors who had proved their usefulness in the bucksaw era have disappeared; that safety instructors are still on the job and when a cutter has developed safe habits and methods, one may consider his training complete.

According to an able operator, apart from having more schooling the woodsworker of tomorrow handling pulpwood combines and allied equipment will be very much like the man we employ today. He will work on an hourly basis, probably with some sort of incentive bonus, and will be trained on the job. He will eventually work on a year-round basis and receive wages and fringe benefits comparable to those enjoyed by his brother at the mill. Maintenance men may have to have somewhat higher qualifications than now. 
As moderator of the C.P.P.A. symposium on labour training last March, John Windebank (1) said:

". . . the piecework system of payment doesn't lend itself well to group effort, and hourly wages alone may not be much better. The old rules concerning absenteeism before and after holidays do not fit in this new type of operation. Yet our labour agreements are written around the old ways of doing things, and when it comes to getting labour agreements changed, our bargaining methods seem quite inadequate."

It seems inconceivable in this era that piecework rates bargained for be more or less taken out of the air. Last spring, the union demands to our company for piecework rates were precisely the same from Gaspe to Abitibi although work conditions vary greatly from region to region. However these were the first collective agreements we had negotiated with the union and their uniformity was probably owing partly to lack of data on which to base more realistic demands. But there is a ray of hope! In one of our divisions an agreement was signed with reasonable spreads between low and high rates to allow for actual conditions after we had suggested a joint committee of union and company representatives study the application of our production standards in the setting of piecework rates. This is a first step which should result in more intelligent bargaining.

Supervision, the art of overseeing, embodies labour training, at least in a broad sense. Considering labour training while ignoring the quality of supervision given woodsworkers would be putting the cart before the horse. The contractor system does not lend itself to organized labour training.

After numerous attempts at training supervisors and contractors during three decades, I have come to the conclusion that those who can really change with training after they have developed set ways and attitudes are exceptions to the rule. A great many hear and remember only those techniques that fit in their previous methods of working. Some are quite satisfied with their present way of doing things or they are completely unaware of their own behaviour and how it strikes others.

To sum up, on-the-job training by the foreman or as helper on machines, or even more, on-the-job self training has so far proved ample to keep up with technical developments, and I see nothing in my crystal ball that indicates a trend or immediate need in the other direction.

A clear picture of the efficient supervisor; an inventory of what we have and selection and development of new recruits before they have already formed detrimental attitudes; a study of the advantages and disadvantages of the contractor system; a close look at living and social conditions of woodsworkers; a fresh and imaginative approach to our methods of bargaining with and paying woodsworkers: these to my mind are problems whose solution is more urgent than labour training.

\section{REFERENCES}

1. WINDEBANK, W. J., GRAINGER, E. E., HARRISON, F. A., and ROBERTS, F, A. 1963. Technical change and its consequences on woods operations. C.P.P.A. Woodlands Sect. Index No. 2217 (B-2). 14 pp.

2. FORTIN, GERALD and EMILE GOSSELEN. 1960, La professionalisation du travail en forêt. Recherches sociographiques 1: 33-60.

3. TREMBLAY, M. ADELARD. 1960. Les tensions psychologiques chez le bûcheron: quelques éléments d'explication. Recherches Sociographiques 1: 61-82. 